\title{
THE UNEASY PULPIT: CARL HENRY, THE AUTHORITY OF THE BIBLE, AND EXPOSITIONAL PREACHING
}

\author{
KEVIN KING* \\ Liberty University
}

\begin{abstract}
It has been asserted that preaching in the first half of the twenty-first century is in crisis by the authors of Engaging Preaching. This crisis has arisen, so say the authors, due in part to those who have been entrusted to preach the 'oracles of God' (1 Peter 4:11), having failed to faithfully proclaim the Word of the Lord. No longer do the words of 'Thus saith the Lord', regularly fill the halls of the sanctuary. Instead of a sure word from the Bible, those in attendance are just as likely to give tips on self-fulfillment or achieving one's dreams. By this practice, it seems there are a significant number of pulpit practitioners who neither trust in the authority or the sufficiency of the Word of God. The situation seems bleak, but there is a remedy to be applied to this situation. Carl F. H. Henry has left us a wealth of theological writings that speak to this very problem. This paper will argue as Henry has masterfully argued for the authority of Scripture, the preacher finds a sure footing for a pulpit practice that displays the authority and the sufficiency of the Bible. It will be argued that expositional preaching is the most natural response to a robust view of the authority and sufficiency of the Word of God.
\end{abstract}

KEY WORDS: authority, sufficiency, preaching, Henry, expositional

\section{Introduction}

Evangelical identity has been and continues to be something of a challenge to define clearly. One might think that with the founding of the National Evangelical Association (1942) and the Evangelical Theological Society (1949) that issues regarding modern evangelical identity would have long been settled. Unfortunately, that has not been the case and apparently still is not. In 1976, Carl Henry wrote a book entitled Evangelicals in Search of Identity. In this book, Henry addressed the missed and lost opportunities of the evangelical movement that threatened evangelicalism with becoming 'a wilderness cult in a secular society' by the year 2000 (Henry 1976: 16). What had looked so promising in the early 1950s for the rising influence of evangelicalism in the United States when Henry characterized the move-

* KEVIN L. KING (PhD 2009, University of Pretoria; DMin 2000, Southern Baptist Theological Seminary; MDiv 1994, Southeastern Baptist Theological Seminary) is Professor of Homiletics and Historical Theology at Liberty University, United States of America. Email: klkingsr@liberty.edu. 
ment, as a lion that had been too long in his cage, and now was ready to burst upon the American scene with a terrible roar and unsuspecting power, was little more, in the late 1970's, than a lion that was on the loose that no one had to fear (Henry 1976: 16, 96). If this was the case at the end of the twentieth century, it seems that in the first decades of the twenty-first, the situation has not improved. If this assessment of the movement as a whole is accurate, the observation when applied to preaching in particular is of acute concern.

'Is there any need of preaching? Is there any place for preaching in the modern Church and in the modern world, or has preaching become quite outmoded?' (Lloyd-Jones 1971: 9). So starts D. Martyn Lloyd-Jones in his classic book on preaching, Preaching and Preachers. It seems to be a very contemporary question and yet, Lloyd-Jones posed this question in 1971. He goes on to bemoan the fact that the question could even be entertained in his day. Lloyd-Jones asserts the role of preaching in the history of the life of the Church is beyond dispute. Preaching and its preachers have always played a central role in the life of the Church (Lloyd-Jones 1971: 11). And yet, not only in the latter half of the twentieth century were there concerns about the condition of preaching, but also it has continued in the first part of the twenty-first century. The contemporary situation in today's preaching has been characterized as a crisis, filled with idle chatter that is comprised of do better and be better sermons that emanate from individualized and privatized faith and seek moral reform (Akin 2011: 1). This therapeutic model has demonstrated remarkable staying power, given that it was popularized through the preaching of Harry Emerson Fosdick (Fosdick 2004: Kindle Location 85-264). The authors of Engaging Exposition express in eloquent fashion the 'Crisis in Twenty-First Century Preaching':

This book reflects a serious concern as well as certain nonnegotiable convictions the three of us hold in common. We believe the church of the Lord Jesus Christ is at a critical point. A crisis is in our pulpits, and this situation is critical. Seduced by the sirens of modernity, preachers of the gospel have jettisoned a word-based ministry that is expository in nature. Skiing across the surface needs of a fallen, sinful humanity, we have turned the pulpit into a pop psychology sideshow and a feel-good pit stop. We have neglected preaching the whole counsel of God's Word.

What has resulted? Too many of our people know neither the content nor the doctrines of Scripture. What is the fallout? Not knowing the Word, they do not love or obey the Word. If the Bible is used at all in preaching, it is usually included as a proof-text that is used out of context and has no real connection to what the biblical author is saying. Many who claim and perhaps believe they are expositors betray their confession by their practice. 
The words of the prophet Amos were never more piercing as they are now: 'Behold, the days are coming', says the Lord GOD, 'that I will send a famine on the land, / Not a famine of bread, / Nor a thirst for water, / But of hearing the words of the LORD. They shall wander from sea to sea, / and from north to east; / They shall run to and fro, seeking the word of the LORD, / But shall not find it' (Amos 8:11-12).

Many pastors are guilty of committing ministerial malpractice on their congregation. By what they do, they indicate that they believe we can see people converted and brought to maturity in Christ without the consistent teaching of the Bible. Further, at least implicitly, they question the judgment of God the Holy Spirit is inspiring Scripture as we now have it. By their method and practice, they suggest that the Holy Spirit should have packaged the Bible differently (Akin 2011: 1-2).

If preaching is indispensable in the life of the Church, and if the current state of preaching is in crisis, what remedies are there to rescue preaching and preachers from such a situation? The author of this paper believes that going back to the past, and significantly to the writings of Carl F. H. Henry, we can chart a way for the future of preaching. Henry is widely recognized as a theological giant, a prodigious writer, and one who believed in the life changing message of the Gospel. Henry is inextricably linked to the modern expression of evangelicalism in the United States of America. He burst onto the scene in 1947 with the publication of The Uneasy Conscience of Modern Fundamentalism. In this rather short book, Henry challenged the obscurantism of modern Fundamentalism and offered instead a call for substantive social engagement. Henry was involved in the founding of the National Association of Evangelicals, the Evangelical Theological Society, Fuller Theological Seminary, and he was the founding editor of Christianity Today. It was his service as editor for twelve years at Christianity Today that gave Henry a platform to articulate and propagate his vision of evangelicalism. Henry played a prominent role in many evangelical events and his theological writings span seven decades culminating in his magnum opus, the six volumes of God, Revelation, and Authority (House 2004: 4-5). Henry is well suited to offer a cogent and coherent prescription for the crisis that preaching faces.

In light of the foregoing description, the thesis of this paper is that there is an inseparable link between Biblical authority and expositional preaching. The one naturally entails the other. To develop this thesis, the paper will summarize the defense of Biblical authority by Carl Henry (noting his philosophical and biblical argument) and conclude by noting several advantages of expository preaching in light of the authority and sufficiency of the Bible for preaching. 


\section{The Crisis of Authority}

'No fact of contemporary Western life is more evident than its growing distrust of final truth and its implacable questioning of any sure word' (Henry 1999: 17). Henry goes on to describe the effect of this 'growing distrust' as having infected nearly every area of Western life as it relates to authority, any authority. Where the West once considered the God of the Bible as the ultimate authority over life, that now has been replaced by personal autonomy that has arisen out of the reigning worldview of naturalism. The rise of personal autonomy has such standing in the academy that Henry writes; "no single moral authority has been recognized by the American academic elite since the late 1930s' (Henry 1994: 45-46).

A chief characteristic of life in the West in the last half of the twentieth century was its attack on any transcendent authority. Self-autonomy became the ruling axiom and shared norm in a culture that saw an incredible dwindling of shared norms. The current fixation on self-fulfillment is the natural fruit of the tree that is rooted in secular humanism. Henry cites Locke and Nietzsche as but two who recognized the inherent destructiveness of this move away from a transcendent God and to the autonomous self. For Locke, Western culture rested on the sure foundation of theistic belief and atheism is a threat to its very survival. Nietzsche understood well the implications of the view that 'God is dead'. Its appropriation 'renders inevitable a comprehensive transformation of the whole of Western culture' (Henry 1994: 46). Henry has not oversold the situation. Two of the major competing worldviews (naturalism and Christianity) offer different conceptualities and realities. From early on in Henry's writings, one can see him take on the very foundations of the competing worldviews. In two of his early works, Remaking the Modern Mind (1948), and the Drift of Western Thought (1951), Henry charts the differences between secular humanism and Christianity. He will then follow up with a masterful summary contained in volume 1 of God, Revelation, and Authority where the reader, once again discovers, that there is no neutral ground between humanism and Christianity. Both offer, in terms of ultimate concerns, very different views of the world; the acquisition of truth and knowing truth being two of the chief differences. It is to this difference that we now turn.

Naturalism is at its core fallacious and untrue. And as one follows its trajectory, it leads to potentially disastrous consequences. Henry affirms this assessment of naturalism, 'the modern naturalistic mind is seriously deranged by false philosophical assumptions about human epistemic power' (Henry 1994: 51).

The prime belief of naturalism is that 'nature is the ultimate real and that man is essentially no more than an animal' (Henry 1948: 22). The consequences of this position are immediate and obvious. If nature is the ulti- 
mate real, then there is no such thing as objective truth and no objective morality. The effects go beyond these startling denials. The end result that if nature is all that there is in the end, then there are no 'gods, souls, values, or anything else-unsubject to time and change' (Henry 1951: 41).

Henry notes that this is not the only time in human history where a naturalistic view of the world and humanity was offered as the overriding explanatory hypothesis for life. The ancient Greeks had their own struggle in this regard. It was the overwhelming defeat of the world-life view presented by Democritus that 'nature is the ultimate real', by Greek idealism that kept naturalism as a subterranean option. Henry writes 'the idealists discerned that Democritean and Sophistic philosophy (a natural outcome of the atomistic view of the nature reality-my comments) offered no basis of a durable Greek culture... A universe in which everything changes is an unintelligible universe...' (Henry 1951: 16).

Not only does the presupposition exists that nature is the ultimate real and that reality is in flux, but naturalism also posits a priori, that in the absence of a transcendent authority, the only authority is self. Selfassertiveness, self-direction and self-fulfillment are but three manifestations of this specter of modernism/postmodernism. This view disallows any reality to the supernatural and transcendent. Naturalism asserts:

1. All reality is reducible to impersonal processes and energy events

2. All life, including human life, is transient and its final destiny is death

3. Truth and the good are culture-conditioned distinctions that the human race projects upon the cosmos and history.

4. The implication is clear: humanity's coming of age requires rejecting all transcendentally fixed and final authority (Henry 1990: 23).

The promise of humanity's coming of age was not realized with modernity. As would be inevitable, given its presuppositions, the assurance of modernity has given way to the perspectivalism and relativity of one's historical localization. Postmodernism is the term that is used to, in some sense, characterize the current day. The term has been around since the 1964 essay by John Cobb, but in the middle of the 1990s the term was gaining common currency from the intellectual elites to the masses (Mohler 2001: 54). Henry cited Beardslee's definition of postmodernism as 'a movement beyond scientistic modernism, one that is breaking away from the determinism of the modern worldview`' (Henry 2001: 34). The definition put forward by JeanFrancois Lyotard seems to be a reference point for many in describing postmodernism: 'incredulity toward metanarratives' (Mohler 2001: 57). Modernity, as defined by Lyotard, attempted to offer an explanatory hypothesis for all of reality, a metanarrative. Lyotard viewed the metanarrative as offered by modernity as having passed from the scene. No longer 
was there the shared consensus in the 'established facts' of science. Modernity's answer to the questions of life with its rationalizations and assertions of certitude were no longer credible. Lyotard writes,

The narrative function is losing its great functors, its great hero, its great danger, its great voyages, its great goals. It is being disbursed in clouds of narrative language elements-narrative, but also denotative, prescriptive, and so on. Conveyed within each cloud are pragmatic valencies specific to each kind. Each of us lives at the intersection of many of these. However, we do not necessarily establish stable language combinations, and the properties of the ones we do establish are not necessarily communicable (Mohler 2001: 57).

The effect of this drift of thought in the West is obvious. No longer are there shared norms that bolstered Enlightenment thought, those have given way to the perspectivalism of post-modern thought. If the sure moorings of foundationalism have given way to the shifting sand of perspectivalism, then the immediate crisis for authority of any kind is readily apparent. The impact on Biblical authority and preaching has been significant. It is into this smoldering cauldron of doubt and distrust that Carl Henry charts a way back to the sure footing found on the solid rock of the Bible and its authority.

\section{Uncertainty and Preaching}

Whereas modernity had given itself to empirical observation and validation as the only acceptable standards of authority, post-modernity questions the very foundation of the once shared consensus of the all wise and sure scientific method (Henry 1948, 1951). Postmodernity embraces the perspectivalism of truth and authority. There is no one overarching truth that everyone is accountable to (minus this one truth), but rather, different communities see truth differently. By what authority should an individual or community acquiesce to a tradition that is simply incongruent with the contemporary mind? (Allen 1997: 36-37) David Buttrick states the current state of questioning authority as plainly as anyone, the "conventional notions of Biblical authority... are no longer tenable and that «we shall have to rethink the nature of authority' (David Allen 2000: 490). To say that this has impacted preaching, distrust of authority, is an understatement and it has just not arrived on the scene with postmodernism (Sexton 2009: 26-49).

Henry's defense of Biblical authority, inspiration and inerrancy were themes that he wrote on or oversaw in numerous books and articles he authored or edited that spanned the decades (Henry 1948, 1962, 1990, 1999). The relevance for preaching is obvious and alarming. As far back as 1949, Henry highlighted the dangers. In The Protestant Dilemma, Henry approvingly quotes Gordon Potcat (We Preach Not Ourselves) who brings to light the 
plight suffered by the Liberalism in the wake of the loss of objective Biblical authority:

The deficiencies of modern topical preaching are becoming widely recognized even among those who have followed the method... The weakness of traditiondetached, non-Biblical preaching is felt by many. The lack of a message is confessed... Aware of this situation, a liberally trained minister will occasionally express nostalgia for the assurance of the fundamentalist, which makes it possible for that brother to use the Bible as the Word of God. The so-called neo-orthodox movement is in larger measure a back-to-the-Bible movement among preachers and theologians who have been trained in the Higher Criticism. But back to the Bible for such men cannot signify a repudiation of what they have learned from their historical studies. They cannot revert to the old authoritarianism of an infallible, inerrant Bible... But can he ever find his authority in the Bible? If he is to make a fresh start at Biblical preaching, how is it to be done? (Henry 1948: $56)$.

It is into this vacuum that Henry mounts a cogent argument for an authoritative Bible that is best served by expositional preaching. Henry builds a theological, biblical and historical argument for the authority of the Bible. It is to those arguments that this paper now turns.

\section{Hath God said? The Problem of Religious Knowledge}

In building his case for the authoritative revelation of God, Henry not only answers the question of what is the source of theology, but also answers the question, how can one defend the conclusions drawn from that data? The bottom line question that needs to be answered is this, how does one know if the statements that emanate from one's theological reflections are true or not? (Henry 1999: 1:14-15). The issue is and has always been an issue of truth. The same question that the Serpent posed to Eve in the Garden of Eden still rings in the ears of the sons of Adam and the daughters of Eve, 'Yea, hath God said?' Henry's answer is absolutely. In volume 1 of God, Revelation, and Authority, he lays out a philosophical and theological foundation for religious knowledge.

How does man know? Can we know beyond our own limited perspectives? The answer is yes. While man may not have exhaustive knowledge, he can have extensive and truthful knowledge. There is no antiseptic path to knowledge. The Christian is within his epistemic rights to start with God, just as the naturalistic philosopher is within his rights to start with eternality of the universe (Henry 1990: 66). What is incumbent on each is to offer a satisfactory explanatory hypothesis for all that there is. Henry is unapologetic in offering a distinctively Christian explanatory hypothesis. Writing to Christian educators and challenging them to articulate a distinctive Christian view of knowing and truth, Henry writes, that unless 'Christian educa- 
tors... expound its way of knowing God, and strenuously proclaims universally valid truth... [it] will survive as but a fading oddity in an academic world that questions its legitimacy and appropriateness' (Henry 1994: 93). Greg Thornbury summarizes Henry's position in a condensed way:

Henry espoused a Reformation-inspired voluntarism in the best sense of the term. He stressed the absolute dependence of human knowledge upon divine disclosure, whether natural or particular. In other words, according to Henry, we know what we know because God wills both the possibility and the content of that knowledge. Henry came to these views early on in his theological career and never wavered (Thornbury 2013: 52).

In articulating a distinctively Christian view of knowledge, Henry asserts that all knowledge is in some sense revelational. How so? God makes the very possibility of knowledge a reality. To hold to anything else, is foreign to a thoroughgoing Christian worldview. The universe, man and knowledge have not developed by evolutionary processes. Man alone does not impose knowledge upon things. Rather, a rational Deity has created an intelligible creation. Man, created in the image of God, has been gifted by the Creator to recognize revelation (Henry 1951: 104).

Henry believes that it is essential for Christianity to state its method of knowing and its principle of verification. This would be true for nonChristian views as well. Henry is answering the question, 'What persuasive reasons have you for believing?' (Henry 1999 1:213). His answer is grounded in two fundamental axioms: the Christian ontological axiom is the living, self-revealed God, and the Christian epistemological axiom, is the intelligible divine revelation (Henry 1990: 68). These two axioms provide the foundation of the essential doctrines of Christianity: revelation (general and special), creation, sin, redemption history, the church in society and eschatology (Henry 1994: 209). It is because of the divine initiative that we have what we have and have the possibility to know what we know. Henry is saying without equivocation, that the source of evangelical theology is made known in God's Word and deed and the depository for God's word and deed is the Bible (Henry 1999: 1:223). Having made his case for a philosophical argument for an intelligible Divine disclosure contained in Scripture, Henry then moves on to build a biblical and historical case for the Bible's authority, not just in matter of faith, but also in all areas of life.

\section{The Bible: Is It Authoritative?}

The Bible has occupied and continues to occupy a prominent place in most contemporary Protestant churches. David Kelsey recognizes the place of the Bible when he writes, 'virtually every contemporary Protestant theologian along the entire spectrum of opinion from the 'neo-evangelicals' through 
Karl Barth, Emil Bruner, to Anders Nygren, Rudolf Bultmann, Paul Tillich, and Fritz Buri has acknowledged that any Christian theology worthy of the name 'Christian' must, in some sense of the phrase, be done in accord with Scripture' (Wells 1990: 156). It is one thing to recognize that, in some sense, things be done in accord with Scripture, but quite another to affirm and hold to the authority of the Bible. This is where, following the very clear and cogent argument for Biblical authority of Carl Henry, he provides a much-needed correction to the postmodern tendency to hold assertions of authority in a tenuous tension. According to Henry, 'the idea of God making Himself known is not so much a biblical idea, as it is the biblical idea' (Henry 1999: 2:18). By returning to the defense of Biblical authority he had been developing for decades, and his most mature articulation of this defense in God, Revelation, and Authority, volume 4, the reader will find a stable platform to stand squarely upon, and proclaim as found in the Old Testament over 3800 times, 'Thus saith the Lord'.

The authority of the Bible is cemented in the self-revealing God. Christian theology is grounded in God's self-revelation and made possible because God has created mankind in His image and given him the ability to recognized revealed truth (Nash 1987: 90). An overview of Henry's conception of Biblical authority can be seen in a statement regarding what might a comprehensive view of God's revelation look like:

It would involve, certainly, the priority of the truth God declares. If revelation isn't intelligible, we're at a loss to say anything about God or his purposes for man... The biblical emphasis falls first and foremost on the authority of Scripture. After that, the emphasis falls, it seems to me, on the inspiration of God's word. It is what God has spoken; that's why it is authoritative. The notion of an authoritative word that isn't God's word, or that isn't inspired, is out of view. Inerrancy seems to me be an inference from the inspiration the Bible teaches. If one denies inerrancy, and affirms errancy, he raises all sorts of questions about inspiration. The affirmation of the errancy of Scripture introduces a principle of instability into the authority of Scripture that leads to a lack of agreement as to what parts of Scripture are to be considered authoritative and what parts are not (Henry 1986: 8).

In God, Revelation, and Authority, thesis eleven states: 'The Bible is reservoir and conduit of divine truth, the authoritative written record and exposition of God's nature and will' (Henry 1999: 4:7). In developing this thesis, Henry opposes those who would assert that any claim to authority is nothing more than a social convention. It seems that in 2015 external authority of any kind is rejected to some degree. The issue was no different as Henry observed in 1976, 'the problem of authority is one of the most deeply distressing concerns in contemporary civilization’ (Henry 1999: 4:7). 
Having made the philosophical argument that God is capable and has revealed Himself to mankind in an intelligible and knowledgeable fashion, Henry sets out to make a biblical case of the authority of the Bible. In Henry's opinion, the place to start making this case, is the Bible's own assertion of its authority. While Henry does not start with the case for inerrancy, in fact he makes one of the most significant defenses of inerrancy in the twentieth century, his main concern is to develop the argument for Biblical authority as found throughout the pages of Scripture (Thornbury 2013: 117). In Scripture you find prophets and apostles who claim to be the authorized spokesman for God. Of course, the preeminent spokesman is the Lord Jesus Christ Himself (Henry 1999: 4:27).

There is a consistent message and theme that God has spoken throughout Scripture. God either speaks Himself directly to select individuals, or through designated prophets in the Old Testament. Theissen notes that this type of speech occurs over 3800 times in the Old Testament (Henry 1999: 4:30-33). What is true for the Old Testament is also found in the New Testament. Here is found the writings of the authorized and commissioned apostles of the risen and resurrected Lord Jesus Christ. Included in this number is the Apostle Paul, who bases his credentials and authority on the personal commission that he had received from the Risen Lord, just as the other apostles had received (Henry 1999: 4:29).

The superiority of Jesus Christ is declared throughout the New Testament. In Hebrews 3:1 (KJV), He is called the Apostle and High Priest. Jesus is trumpeted as the complete and final revelation of God who absolutely authorizes His word (Apostle) and his work (High Priest). Jesus is the Apostle sent by the Father, as Jesus Himself states in the high priestly prayer (John 17:18), in and by whom the Father acts (John 14:10), and who in turn authorizes the apostles for their world mission (John 20:21) (Henry 1999: $4: 28)$.

The thread that binds the Old Testament prophets and the New Testament apostles is that they are both preaching and delivering a divinely authorized message. The Old Testament books were recognized as divine communication by Jesus, the apostles and the primitive church. The oral and public proclamation, and later the writings of the apostles, were made based on their understanding as being the divinely authorized communicators of God's Word. Paul makes an unambiguous claim to such authority even as his apostolic authority was being questioned: 'our authority-an authority given by the Lord' (Henry 1999: 4:30-33). It is interesting to note, the prophets of the Old Testament and apostles of the New Testament, their authority has not been transferred to any subsequent group. Rather, their authority is found in the written Word of God-the Bible. Henry quotes William C. G. Procter appropriately: 'it is through the Bible that Jesus 
Christ now exercises his divine authority, imparting authoritative truth, issuing authoritative commands and imposing an authoritative norm by which all the arrangements or statements made by the church must be shaped and corrected' (Henry 1999: 4:39).

\section{Biblical Authority and Expositional Preaching}

An underlying goal of this article is to continue to make the argument for expositional preaching. As has been mentioned, the condition of preaching in the United States of America in the early twenty-first century is in crisis. What criterion is there that would verify such a statement? The eye test is all that the reader needs to know that something is not quite right in the evangelical church, broadly speaking, in our day. By any measure, the evangelical church is less relevant and impactful that in days gone by. It is not the contention of the writer to lay all the blame on the preacher in the pulpit, but in some respects, as the pulpit goes so goes the church.

Following Henry's argument that a rational God has created an intelligible universe, and has revealed Himself in a discoverable and intelligible way through the Bible; and given the fact, that from the time of the prophets in the Old Testament, to the words of Jesus and the letters of the New Testament, the Church has viewed the Bible as the Word of God. If this is the case, what implications are there for preaching? The implications are profound:

Our responsibility as preachers now begins to emerge. This is primarily to give our twentieth-century testimony to Jesus (most Western preaching today tends to be too subjective), but rather to relay with faithfulness to the twentieth century (and endorse with our own experience) the only authoritative witness there is, namely God's own witness to Christ through the first-century apostolic eyewitnesses. In this respect the Bible is unique. It is 'God's Word written', since here and only here is God's own interpretation of his redeeming action to be found (Stott 1982: 98).

John Stott has framed the responsibility of the preacher perfectly. How does a preacher fulfill his responsibility faithfully to 'God's Word Written?' He preaches expositionally.

Expositional preaching has been defined in a number of ways, from John Broadus, Charles Koller, Haddon Robinson, W. A. Criswell to Danny Akin. A common thread that runs through these various definitions is the ascertaining of authorial intent through the historical-grammaticaltheological interpretation of the Text, and then communicated by the preacher to the audience so the divinely authorized message is understood and then applied to the life of the listener(s). Haddon Robinson's definition has been a standard since the publication of his book in 1980. It reads: 
Expository preaching is the communication of a biblical concept, derived from and transmitted through a historical, grammatical, and literary study of a passage in its context, which the Holy Spirit first applies to the personality and experience of the preacher, then through him to his hearers (Robinson 1980: 19).

Expositional preaching, or the lack of it, was a concern to Carl Henry. '... Henry once complained about the relationship between the parachurch evangelicalism he championed mid-century and the decline of the worship of the church. 'Our youth camps were so successful that now all our worship church services try to mimic our youth camps...' (Moore 2004: 30). Henry believed that a key aspect of the church's task was doctrinallyanchored expositional preaching. Unfortunately, Henry's observation concerning the success of church youth camps was observed in preacher's foregoing solid exegetical study, for a sermonic approach that would keep things light. As evangelicalism continued to search for its identity, the sermon was but the most telling sign of the movement's crisis. Instead of sermons that substantively engaged Scripture and followed the contours of redemption history, the sermon catered to the desires of the listeners. Henry noted, 'nominal Christians prefer vague generalities, enhanced by the eloquence of Athens and have no taste for the soul-searching truths of Jerusalem' (Moore 2004: 29).

Expositional preaching not only fulfills the preacher's responsibility to God's Word, but it is also the best model of preaching to instruct people in how to study the Scriptures. As the pastor models his particular approach to preaching, it will over time, begin to impact his church. If the pastor preaches topically, the congregation, will over time begin to read and think about Scripture topically. If he preaches expositionally, it will have the effect, that his congregation will develop an appetite for sustained and substantive engagement with the Scriptures' (Meyer 2013: 286).

Expositional preaching has biblical warrant. Jason Meyer in his book, Preaching: A Biblical Theology, lists six arguments he draws from the Scriptures to argue for expositional preaching being thoroughly biblical:

1. Biblical examples and biblical commands point to the concept of expository preaching in seed form.

2. God spoke specific words and entrusted them to stewards.

3. God's specific words were written in a specific form with God's authorization.

4. Scripture abounds with warnings not to twist or add to God's word.

5. Preaching in Scripture will shift somewhat according to the specific stage of redemptive history.

6. Expository preaching is a multifaceted philosophy involving more than just a biblical theology of preaching (Meyer 2013: 272-279). 
Expository preaching demands that the preacher make a philosophical commitment that the Text is in control of his sermon. The biblical writer determines the subject and substance of the expositional sermon. Robinson writes, 'Expository preaching at its core is more a philosophy than a method' (Robinson 1980: 22). Expositional preaching starts with a precommitment that the Word of God is authoritative and sufficient. The preacher has absolute confidence in the Scriptures in matters of faith, practice and all areas where Scripture speaks or makes assertions.

\section{Conclusion}

Evangelicalism was once thought to be a movement that would soon burst onto the American scene and roar like a lion. This was Carl Henry's hope and description of evangelicalism before 1976. But it would be in that year, Henry would have to admit, while the lion had emerged from his cage, he was no longer feared. Evangelicalism was in trouble as were evangelical pulpits. Unfortunately, the situation has not improved except in some localized instances. This paper has attempted to offer a remedy to the current situation. The author of this paper believes the way forward can be discovered by going back. By going back to the writings of Carl Henry, a theologian who wrote for over seven decades and was a significant evangelical voice from the middle to the turn of the twentieth century, evangelicals can reclaim their once vibrant theological heritage. In the writings of Carl Henry, one can find a robust defense of biblical authority that stands in stark contrast to the prevarications and equivocations that attempt to make theology palatable to postmodern sympathies. Henry builds his defense of biblical authority through a vigorous philosophical exposition of his ontological and epistemological axiom, while identifying and answering the objections to authority. He then examines the biblical record regarding the Divine disclosure. By following the contours of Henry's defense of biblical authority, a preacher can stand with confidence and assurance as he proclaims God's Word, that the Bible he preaches from is 'God's Word Written'. It was then argued that expositional preaching is the best model of preaching to meet the preacher's responsibility to faithful let God speak and not speak for God. It is expositional preaching, that is the method that stands on Biblical authority and with no equivocation or hesitation says, 'The Word of God, for the people of God, thanks be to God!'

\section{Bibliography}

Akin DA (2011) Engaging Exposition. Nashville, TN: B\&H Publishing Group. Allen D (2000) A Tale of Two Roads: Homiletics and Biblical Authority. Journal of the Evangelical Theological Society 43(3): 490. 
Allen RJ (1997) Theology for Preaching: Authority, Truth and Knowledge of God in a Postmodern Ethos. Nashville, TN: Abingdon Press.

Fosdick HE (2004) What's the Matter with Preaching? In Graves M (ed) What's the Matter with Preaching Today. Louisville, KY: Westminster John Know.

Henry CFH (1948) The Protestant Dilemma. Grand Rapids, MI: Wm B. Eerdmans Publishing Company.

Henry CFH (1951) The Drift of Western Thought. Grand Rapids, MI: Wm. B. Eerdmans Publishing Company.

Henry CFH (1976) Evangelicals in Search of an Identity. Waco, TX: Word Books.

Henry CFH (1986) Conversations with Carl Henry: Christianity for Today. Lewiston, NY: Edwin Mellen Press.

Henry CFH (1990) Toward A Recovery of Christian Belief. Wheaton, IL: Crossway Books.

Henry CFH (1994) The Crisis of Authority. In Mohler A (ed) The god of this Age or the God of the Ages. Nashville, TN: Broadman \& Holman.

Henry CFH (1994) Shall We Flunk the Educators? In Mohler A (ed) The god of this Age or the God of the Ages. Nashville, TN: Broadman \& Holman Publishers.

Henry CFH (1999) God, Revelation, and Authority, volumes 1-6. Wheaton, IL: Crossway Books.

Henry CFH (2001) Postmodernism: The New Spectre? In Dockery D (ed) The Challenge of Postmodernism, 2nd edition. Grand Rapids, MI: Baker Academic.

House PR (2004) Remaking the Modern Mind: Revisiting Carl Henry's Theological Vision. Southern Baptist Theological Journal 8(4): 4-5.

Lloyd-Jones DM (1971) Preaching and Preachers. Grand Rapids, MI: Zondervan House.

Meyer J (2013) Preaching: A Biblical Theology. Wheaton, IL: Crossway.

Mohler A (2001) The Integrity of the Evangelical Tradition and the Challenge of the Postmodern Paradigm. In Dockery D (ed) The Challenge of Postmoderism, 2nd edition. Grand Rapids, MI: Baker Academic.

Moore R (2004) God, Revelation, and Community: Ecclesiology and Baptist Identity in the Thought of Carl F. H. Henry. Southern Baptist Journal of Theology 3(*): 30 .

Nash R (1987) Evangelicals in America. Nashville, TN: Abingdon.

Robinson H (1980) Biblical Preaching: The Development of the Expository Messages. Grand Rapids, MI: Baker Books.

Sexton JS (2009) How Far Beyond Chicago? Assessing Recent Attempts to Reframe the Inerrancy Debate. Themelios 34(1): 26-49. 
Stott J (1982) Between Two Worlds. Grand Rapids, MI: Wm. B. Eerdmans Publishing Company.

Thornbury G (2013) Recovering Classic Evangelicalism. Wheaton, IL: Crossway.

Wells D (1990) Word and World: Biblical Authority and The Quandary of Modernity. In Henry CFH (ed) Evangelical Affirmations. Grand Rapids, MI: Zondervan Publishing House. 